Politttinen talous 2(2014):1, 34-67

Altarriba

\title{
ONKO YLIOPISTO- JA TIEDEMAAILMA SUISTUMASSA SPEKULATIIVISEEN KUPLAAN? Pohdintaa Shillerin kuplateorian pohjalta
}

\section{Elias Altarriba}

\begin{abstract}
Abstrakti
Tässä artikkelissa pohditaan mahdollisuutta, että yliopisto- ja tiedemaailmaan on kehittymässä spekulatiivinen kupla, sekä tämän ilmeneviä tunnusmerkkejä. Asiaa tarkastellaan Shillerin spekulatiivisten kuplien kehitysteoriaan nojautuen. Erityisesti kiinnitetään huomiota suistumistekijöiden ja vahvistusmekanismien tarkasteluun. Nykymuotoinen julkaisukäytäntö, yksinkertaistettujen mittareiden laaja käyttö monimutkaisten asiakokonaisuuksien tarkastelemiseksi sekä rahoituksen järjestäminen näiden mittareiden antamien tulosten perusteella muodostavat itseään vahvistavia takaisinkytkentämekanismeja. Näissä mekanismeissa kasvun ja mahdollisuuksien rajat tulevat jossain vaiheessa vastaan. Lopuksi pohditaan myös yleisluontoisesti kuplan saturaatiopisteen saavuttamista ja sen mahdollisia seurauksia.
\end{abstract}




\section{Johdanto}

Yliopisto- ja tiedemaailma on kuluneen kahdenkymmenen vuoden aikana ollut suurten muutosten kourissa (Hakala ym. 2003, 9-27; Hautamäki \& Ståhle 2012, 9-14; Koski 2009, 101-112; Pakkasvirta 2009, 58; Patomäki 2005, 11-12 ja 74-82). Tämä muutos liittyy läheisesti jälkiteollisen ajan yhteiskunnalliseen murrokseen kohti tietoyhteiskuntaa, jolle tyypillistä on lähes reaaliaikaisesti toimivat globaalit mediat ja muut tiedonsiirtomenetelmät. Tietoyhteiskuntatalouden kehityksen yhtenä suuntana on toistaiseksi ollut markkinoiden laajeneminen erilaisiin ratkaisu- ja immateriaalituotteisiin, mikä on poikkeavaa verrattuna teolliselle yhteiskunnalle tyypillisiin kulutustavara- tai niihin läheisesti liittyvien palveluiden markkinoihin (Castells \& Himanen 2001, 13-20; Sitra 1998, 6). Yksi tällainen talouden immateriaalinen osa-alue on uuden tiedon tuottaminen, mitä toteutetaan laajasti muun muassa yliopistoissa tehtävässä tutkimuksessa.

Tutkimustoimintaa tehdään merkittävissä määrin myös yliopistojen ulkopuolella, mutta etenkin yritysten tuottamaa uutta tietoa halutaan yleensä levittää eteenpäin lähinnä asiakkaille myytävien valmiiden tuotteiden tai ratkaisujen muodossa. Tähän perustuu ehkä merkittävin ero tieteenteon ja yritysten tekemän tutkimus- ja tuotekehitystyön välillä. Tieteellisen tiedon tuottamisen perusperiaatteet edellyttävät sekä tämän uuden tiedon, että sen saavuttamiseksi johtaneen päättelyketjun avoimuutta kritiikin mahdollistamiseksi ja tätä kautta korjaavuuden ja edistymisen varmistamiseksi (Niiniluoto 1997, 60-88). Tämän mahdollistamiseksi tieteenteossa saavutetut tulokset tulisi saattaa julkisesti saataville kullekin ajalle sopivien julkaisukäytänteiden avulla. Tietoliikennetekniikan nopea kehitys on tarjonnut tälle prosessille huomattavasti paremmat puitteet. Erityisesti internet on nopeasti laajentuessaan mullistanut tiedon jakelumahdollisuudet. Käytännössä tietotekniikka mahdollistaa liki kustannuksitta otettavat kopiot tietopaketeista, jotka voidaan lähes reaaliaikaisesti toimittaa melkein minne päin maailmaa tahansa. Muutos on siis todella suuri.

Tietoyhteiskunta on kuitenkin internetin tarjoamista monipuolisista mahdollisuuksista huolimatta kehittynyt suuntaan, missä yksityiset kustannusyhtiöt hallitsevat tieteellisen datan julkaisumarkkinoita (Beverungen ym., 2012). Tähän on johtanut monimutkainen prosessi, jonka seurauksena tietoyhteiskunnalle tärkeää yliopistolaitosta ja tieteenteon perinteitä 
on muokattu vähitellen soveltumaan paremmin koulutuksen ja tieteenteon (ainakin osittaiseksi) kaupallistamiseksi. Prosessia ovat myös merkittävästi ohjanneet tekijänoikeuslainsäädäntöön, globalisaatioon ja yliopistolaitokselle asetettuihin tiedepoliittisiin tavoitteisiin liittyvät poliittisen valinnat (Hakala 2003, 146-191; Nieminen 2003, 48-96; Tomperi 2009, 145-202). Monien länsimaiden tapaan myös Suomessa julkista sektoria on haluttu tehostaa uusliberaalien menetelmien mukaisesti (Patomäki 2005; Patomäki 2009). Tämä on käytännössä tarkoittanut uuden julkisjohtamisen opin laajaa soveltamista muun muassa tiedemaailmaan ja yliopistolaitokseen, sisältäen pitkälle viedyn tutkimustyön mittaus- ja arviointikulttuurin ja managerialistisesti toteutetut suoraviivaiset johtamiskäytänteet (Billaut ym. 2009; Hussain 2013; Koski 2009, 106-112; Patomäki 2005, 83-115 ja 144-165; Tomperi 2009, 145-202). Nämä tekijät ovat osaltaan luoneet pohjaa nykytilanteelle, jossa tutkimustyön tulosten julkaisutoiminnasta on kehittynyt kustannusyhtiöille erittäin tuottoisaa liiketoimintaa (Beverungen ym. 2012; Bohannon 2013; Cederström \& Hoedemaekers 2012).

Julkaisumarkkinat toimivat monessa mielessä varsin eriskummallisella tavalla. Useimmissa tapauksissa yhteiskunnan varoilla tehtävän tutkimustyön tuloksista kertovien artikkeleiden tekijänoikeudet luovutetaan vastikkeetta tiedelehden omistavalle kustannusyhtiölle, joka myy artikkelia takaisin tutkijakunnalle kalliiseen hintaan (Beverungen ym. 2012). Lainsäädäntö ja vallitseva mittauskulttuuri takaavat kuitenkin osaltaan tämän käytännön jatkumisen ainakin toistaiseksi (Butler \& Spoelstra 2012; Opetusja kulttuuriministeriö 2013a; Tekijänoikeuslaki 1961; Vähämäki 2009, 120, 124-125). Tässä voidaan nähdä myös erinomainen esimerkki tilanteesta, jossa markkinavoimat vuorovaikuttavat hyvin läheisesti yhteiskunnan poliittisen toiminnan kanssa (Patomäki 2005, 62-66, 75-80; Volanen 2009, 130). On kuitenkin syytä muistaa, että markkinavoimat perustuvat viime kädessä ihmisten ja ihmisryhmien väliseen vuorovaikutukseen, johon sisältyvät monimutkaisten valtasuhteiden lisäksi myös kaikkien markkinoiden perustana oleva kysyntä ja tarjonta inhimillisten tarpeiden täyttämiseksi.

Markkinatuotteiden arvon määrittäminen on markkinoiden toiminnan kannalta keskeinen kysymys. Usein arvonmääritysvälineenä on käytetty rahaa. Käsitys rahan luonteesta ja sen arvosta ovat vaihdelleet eri aikakausina ja erilaisten poliittisten linjausten mukaan, mutta eri näkökulmista huolimatta etenkin modernilla ajalla keskeiset kaupalliset arvonmääritysprosessit 
perustuivat yleensä rahaan, minkä kansallisvaltion keskuspankki oli laskenut liikkeelle. 1900-luvun kuluessa erityyppisistä arvopapereista ja muista finanssi-instrumenteista on tullut jatkuvasti tärkeämpi menetelmä määriteltäessä objektien kaupallisia arvoja. Sinänsä keskuspankin liikkeelle laskeman rahan rinnalla olevat muut arvonmääritysmenetelmät eivät ole mikään uusi asia, sillä esimerkiksi alkutuotantoon perustuneessa maatalousyhteiskunnassa maanomistus- ja hallintakysymykset olivat usein rahaa keskeisempi talouspoliittinen kysymys. Tämä näkyi muun muassa aika-ajoin toistuvina maareformivaatimuksina, joista usein kehkeytyi jopa verisiä yhteenottoja (Cameron 1997, 44-77).

Tietoyhteiskunnassa tiedon ja datan tuottaminen, niiden hallussapito ja tunnustettu asiantuntijuus ovat nousseet entistä tärkeämpään asemaan, jonka kohdalla voidaan nähdä piirteitä myös osittain rahasta irrallisena tapahtuvaan arvottamiseen (Patomäki 2005, 120-127; Vähämäki 2009, 124-125). Otetaan esimerkiksi vaikkapa suomalaisen yliopistotutkinnon arvo. Onko se määriteltävä siihen sisältyvien opintojen yliopistolle ja yhteiskunnalle aiheuttamana rahallisena kustannuksena, tulisiko se määritellä opintojen aikana oletettavasti kasvaneen osaamisen myötä myöhemmin työelämässä tuotettuna arvonlisäyksenä vai olisiko syytä käyttää jotain täysin muuta lähestymistapaa? Asia on siis arvonmäärittelyä ajatellen monimutkainen, eikä selkeää tai edes suurin piirtein yksikäsitteistä ja kiistatonta ratkaisua ole esitetty. Samaan aikaan Suomessakin puhutaan innokkaasti korkeakoulutuksen tuotteistamisesta ja siihen kiinteästi liittyvästä koulutusviennistä mahdollisine lukukausimaksutuottoineen (Opetus ja kulttuuriministeriö 2013b; Palonen 2009, 45-46).

Myös tieteellisen tutkimuksen tuottaman uuden tiedon arvon määrittely rahaperusteisesti on hankalaa. Jonkin tieteellisen tiedon tai teorian arvo on lisäksi vahvasti riippuvainen suhteessa muuhun tietoon ja yhteiskuntaan. Esimerkiksi jokin uusi sovellus tai vaikkapa yhteiskunnallinen muutos voi muuttaa jonkin teorian tai muun tieteellisen tiedon arvoa suhteessa johonkin toiseen tieteelliseen tietoon. Tieteellisen tiedon arvon erityispiirteistä huolimatta yliopisto- ja tiedemaailmassa on otettu laajasti käyttöön arvonmääritysinstrumentit, joita usein kutsutaan vain yleisnimityksellä mittarit (Adler \& Harzing 2009; Cederström \& Hoedemaekers 2012; Koski 2009, 106-112; Nieminen 2003, 39-42; Palonen 2009, 48; Patomäki 2005, 103-115; Volanen 2009, 129-130). Niillä tarkoitetaan monenlaisia, usein 
suhteellisen yksinkertaisia tapoja arvioida numeerisesti jonkin tieteellisen työn osa-alueen arvoa. Tunnetuimpia mittareita ovat yliopistojen rankinglistat (esimerkiksi Shanghain lista) ja tiedelehtien laatulistat (esimerkiksi ABS-lista tai vaikuttavuusindeksi), minkä lisäksi tutkijoiden tai tutkimusryhmien arvoa evaluoidaan monilla muilla vastaavilla rankkauksilla (Willmott 2011).

Näiden mittareiden laajamittainen käyttöönotto on ollut osa yliopistoinstituution uusliberalistista muutosprosessia sekä Suomessa että ulkomailla. Tavoitteena on ollut tehokas ja oikeisiin strategisiin tavoitteisiin sitoutunut yliopistolaitos. Tämän juhlavan tavoitteen saavuttamiseksi on yritysmaailmasta kopioitu erityisesti tulosjohtamisen käytäntöjä tieteentekoon ja opetukseen. Erilaisten työ- ja toimintakulttuurien yhteensovittaminen ei ole tapahtunut ongelmitta (Hakala ym. 2003, 13-22; Koski 2009, 106-112; Patomäki 2005, 58-82), ja tämän prosessin rakenteellisesta laajuudesta johtuen sen monet ominaispiirteet voivat olla vasta paljastumassa.

Robert Shillerin (2000) teoria spekulatiivisten kuplien synnystä, kehittymisestä ja puhkeamisesta lähestyy talouskuplia osin taloustieteen, osin joukkopsykologian näkökulmasta. Shillerin teoria olettaa jokaisen kuplakehitykseen suistuvan talouden sisältävän suistumistekijöitä ja vahvistusmekanismeja, mitkä sopivissa olosuhteissa muodostavat itseään vahvistavan systeemin. Suistumistekijät eivät ole suoraan kytköksissä kuplakehitykseen suistuviin markkinoihin, vaan määrittävät reunaehdot systeemin kehittymiselle. Vahvistusmekanismit ovat takaisinkytkentäsilmukoita, joiden seurauksena systeemi vahvistaa itseään kehittymään edelleen entistä tehokkaammin.

Shillerin teorian joukkopsykologinen lähestymistapa olettaa yksilöiden tekevän usein päätöksiään seuraten muiden, ympärillä olevien ihmisten muodostaman "lauman" tekemiä ratkaisuja. Yksilölle turvallisilta tuntuvat ratkaisut ovat tyypillisesti niitä, joita "kaikki muutkin" ovat tehneet. Tämä olettamus on keskeisessä osassa kuplan muodostumisen kannalta, sillä laumakäyttäytymisen seurauksena riittävän suuret ihmisjoukot lähtevät tekemillään ratkaisuilla mukaan kuplaan suistuvaan talouskehitykseen. Yksilöillä on havaittu olevan taipumusta niin sanottuun liialliseen itsevarmuuteen, millä tarkoitetaan, että yksilöt uskovat helposti heidän omien ratkaisujensa olevan vähintään yhtä hyviä (ellei jopa parempia), kuin ihmisten ratkaisut keskimäärin. Laumakäyttäytymisen mahdollistamisen kautta uutisilla ja 
muilla medioilla on merkittävä vaikutus kuplan kehittymiseen. Internet on näistä medioista ylivoimaisesti tehokkain ja monipuolisin.

Pohdin alla, onko nykyinen poliittinen kehitys luomassa yliopisto- ja tiedemaailmaan spekulatiivista kuplaa. Aiemmin sellaiset suhdannevaihtelut, joiden on usein vasta voimakkaan laskukauden jälkeen katsottu täyttäneen spekulatiivisen kuplan määritelmän, ovat yleensä tapahtuneet yksityisellä sektorilla toimivien yritysten ja niiden rahoitukseen läheisesti vaikuttavien pankkien ja finanssimarkkinoiden toiminnan kestämättömyyden seurauksena (Kiander 2001, 16-22, 40-48; Shiller 2000, 3-16). Tämänkaltainen otaksuttu spekulatiivinen kupla, missä toimintaympäristönä on yliopisto- ja tiedemaailma, olisi siis uudentyyppinen ilmiö.

Näin suurten ilmiöiden tarkastelu globaalissa yliopisto- ja tiedemaailmassa vaatii paljon tutkimustyötä, eikä varmuutta asioihin voida saada muutoin kuin ajan saatossa. Tämän seurauksena on siis osittain epäselvää, missä määrin esimerkiksi Shillerin esittämää teoriaa (Shiller 2000) spekulatiivisten kuplien syntymisestä ja kehityksestä voidaan soveltaa yliopisto- ja tiedemaailmaan. Toisaalta on kuitenkin myös syytä muistaa, että ihmisten vuorovaikutuksesta, tarpeiden täyttämisestä nousevasta kysynnästä ja niihin saatavien ratkaisujen tarjonnasta sekä näihin seikkoihin läheisesti liittyvistä monentyyppisistä valtasuhteista seuraava kehitys on kuitenkin monessa mielessä universaalia ja asioiden kategorisoinnit ovat lopulta vain talouspoliittisesti sovittuja rajaviivoja. Muutettaessa yliopistoa ja tiedeyhteisöä vapaasti kilpailtujen markkinoiden kaltaiseksi toimintaympäristöksi, on hyvin todennäköistä, että myös vapailla markkinoilla esiintyneet haitalliset ilmiöt tulevat ajan myötä esiin myös yliopistosektorilla. Tässä artikkelissa on tähän laajaan ongelmaan otettu perusnäkökulmaksi suomalainen yliopistomaailma, mutta yliopisto- ja tiedemaailman kansainvälisyydestä johtuen on katsantokantaa laajennettava monissa tapauksissa myös Suomea laajemmalle. 


\section{Spekulatiivisen kuplan mahdollisuus yliopisto- ja tiedemaailmassa}

\subsection{Järjetön innostuneisuus yliopisto- ja tiedemaailmassa}

Spekulatiivisiksi kupliksi katsotaan markkinatalouden suhdannevaihteluiden seurauksena, otollisten olosuhteiden vallitessa muodostuneet suhdanteiden poikkeuksellisen suuret nousukaudet, joita seuraa markkinoiden äkillinen romahdus. Spekulatiivisia kuplia on ilmennyt teollisuudessa, sekä erityisesti pankkisektorilla ja asuntomarkkinoilla (Kiander 2001, 23-46; Shiller 2000, 3-16). Toistaiseksi yliopistosektorilla ei tiedetä ilmenneen spekulatiivisia kuplia. Tämänkin johdosta on oltava varovainen puhuttaessa markkinatermein yliopistomaailman ja tieteenteon ilmiöistä. Kuitenkin on syytä huomioida, että yliopistosektoria on muunnettu niin Suomessa kuin muuallakin maailmassa rakenteiltaan markkinavetoisemmaksi (Cederström \& Hoedemaekers 2012; Hakala ym. 2003, 9-27; Pakkasvirta 2009, 58; Patomäki 2005, 62-66 ja 74-82). Muun muassa uuden tiedon tuottamista on pyritty tuotteistamaan julkaisuiksi, opiskelijat on haluttu nähdä asiakkaina ja systeemin ohjauksessa tulosjohtaminen on nähty soveltamiskelpoiseksi menetelmäsi. Tämän vuoksi yliopisto- ja tiedesektorin tarkastelu käyttämäll̈̈ soveltuvin osin vapaiden markkinoiden teoriaa ei ole niin kaukaa haettua kuin se olisi ollut vaikkapa humboldtilaisia ihanteita seuranneessa yliopistoinstituutiossa.

Yliopistosektori on perinteisesti ollut melko lailla riippumaton vapailla markkinoilla vaikuttavien suhdannevaihteluiden suhteen. Tämä johtui osittain yliopistolaitoksen sen varsin pitkälle viedystä institutionalis-individualistisesta luonteesta, joka päti varsin monella portaalla ja joka osaltaan esti tehokkaasti spekulatiivisille kuplille tyypillisten takaisinkytkentöjen muodostumisen. Opiskelijat kouluttautuivat pääasiassa omien intressiensä tähden, tiedettä tehtiin pienemmissä piireissä ja päähuomio työssä keskittyi julkaisutuotannon sijasta varsinaiseen ongelmien ratkaisuun ja uuden tiedon tuottamiseen (Palonen 2009, 45-46; Patomäki 2009, 27-28; Ylijoki 2009, 83-85). Tuloksista ei palkittu rahallisesti sen enempää tekijää kuin laitostakaan, vaan hyvin tehdystä työstä seurasi professionaalista kunniaa. Yliopisto organisaationa toimi Suomessa suhteellisen demokraattisesti kollegiaalisessa hengessä ja rahoitus toteutettiin valtion varoin 
opetusministeriön budjetista. Myös monissa muissa maissa yliopistoja on perinteisesti rahoitettu verovaroin. Markkinoiden suhdanteiden vaihtelu ja muut markkinoiden aiheuttamat paineet suodattuvat tällöin lainsäädännön ja politiikan asettamien reunaehtojen läpi.

Shiller (2000) kuvaa spekulatiivisen kuplan syntymistä järjettömäksi innostuneisuudeksi ja perustelee taloudelliseen ylikuumentumiseen johtavaa prosessia ihmisjoukkojen joukkopsykologian näkökulmasta. Tämänkaltaiseen kehitykseen johtaviksi keskeisiksi tekijöiksi hän mainitsee ympäröivästä yhteiskunnasta nousevat suistumistekijät ja osittain niiden välillä vaikuttavat prosessia kiihdyttävät takaisinkytkentäsilmukat. Lisäksi näitä vahvistusmekanismeja tehostavat ihmisten taipumus laumakäyttäytymiseen, jota vastaavasti tukee uutisten ja muiden medioiden laajamittainen vaikutus. Asiaan vaikuttavat myös optimistinen suhtautuminen tulevaan ja suurten muutosten tuoma usko uuteen, valoisampaan ja parempaan aikakauteen.

\subsection{Suistumistekijät}

Shillerin mukaan jokaisella spekulatiivisella kuplalla on suistumistekijöitä (Shiller 2000, 17-19). Nämä suistumistekijät eivät itsessään vielä aiheuta markkinoiden ylikuumenemista, mutta niiden katsotaan muodostavan otolliset olosuhteet ylikuumentumiseen johtavalle kehitykselle. Näiden suistumistekijöiden tunnistaminen on keskeistä, mikäli tavoitteena on ymmärtää mahdollisen spekulatiivisen kuplan kehitystä.

Yliopistolaitoksen perustehtäviksi on Suomessa määritelty kansainväliseen tapaan opetus ja tutkimus (Yliopistolaki 2009). Ideaalisesti ajateltuna yliopiston opetustoiminnalla tarkoitetaan kaikkia toimenpiteitä ja ilmiöitä, jotka liittyvät opiskelijan ja opettajan välisen suhteen ympäristöön ja tutkimustoiminnalla yliopistoyhteisön jäsenten työtä uuden tiedon tuottamiseksi. Mikäli tämän määritelmän mukaiset asiat nähdään yliopistotoiminnan "ydinosaamisalueena", voidaan Shilleriä soveltaen (Shiller 2000, 17-19) suistumistekijöitä etsiä välittömästi tämän toimintaympäristön läheisyydestä. Spekulatiivisen kuplan kehitysvaiheessa myös suistumistekijöiden määrittäminen perustuu usein hypoteeseihin, erityisesti tämän kaltaisessa tapauksessa, jossa aiempia vertailutapahtumia ei ole olemassa. 
Mahdollisia suistumistekijöitä ovat ainakin taulukossa 1 (satunnaisessa järjestyksessä) esitetyt tekijät.

\begin{tabular}{|ll|}
\hline Yliopistopolitiikka & Tekijänoikeuslainsäädäntö \\
Tieteelliset julkaisut & Kustantajien toiminta \\
Internet ja muut mediat & Mittauskulttuuri \\
Globalisaatio & Meritokratia \\
\hline
\end{tabular}

TAULUKKO I: SUISTUMISTEKIJÄT

Mielenkiintoinen piirre näissä suistumistekijöissä on kansallisen ja globaalin yliopistotoiminnan suhde. Kaikkia voidaan pitää luonteeltaan kansainvälisinä suistumistekijöinä, mutta niiden saattaminen käytäntöön vaatii aina myös kansallisen yliopisto- ja tiedepoliittisen hyväksynnän. Tässä listassa esitettyjen tekijöiden lisäksi muitakin suistumistekijöitä todennäköisesti löytyy, ja mitä todennäköisimmin myöhemmin aiheesta mahdollisesti tehtävät lisätutkimukset paljastavat myös painotuseroja mainittujen tekijöiden välillä. Käsittelen näiden suistumistekijöiden luonnetta tarkemmin luvuissa 2.2.1 - 2.2.7.

\subsubsection{Yliopistopolitiikka}

Yliopisto- ja tiedepolitiikka on yksi keskeinen alue, jolla Suomen (monien muiden valtioiden ohella) oletetaan olevan tulevaisuudessa menestyvä ja kilpailukykyinen (Castells \& Himanen 2001, 149-160; Hautamäki \& Ståhle 2012, 71-109). Tämä poliittinen linjaus on ollut toistaiseksi luonteeltaan vahvasti uusliberalistinen. Valtion roolia erityisesti yliopistojen toiminnan rahoituksessa on haluttu vähentää (Pakkasvirta 2009, 58; Patomäki 2005, 58-82; Volanen 2009, 130). Yliopistoinstituutiosta on tehty tulosvastuullinen käyttämällä monenlaisia yksinkertaistavia mittareita määrittämään luonteeltaan monimutkaisten suoritusten keskinäisiä taso- ja arvoeroja (Hussain 2013; Koski 2009, 106-112; Willmott 2011). Viimeisin merkittävä askel Suomessa tällä tiellä on ollut vuoden 2010 alusta uuden yliopistolain voimaanastuminen (Tomperi 2009, 145-202; Yliopistolaki 2009). Tämän lain myötä yliopistoista tehtiin oikeushenkilöitä ja niiden rahoitusmallia muutettiin radikaalisti, painottaen yliopistojen omaa rahanhankintaa. 
Johtamiskäytänteiden muutokset mahdollistivat yliopistojen tulosvastuun tehokkaan seurannan, tarkoittaen lähinnä tutkinto- ja tutkimusjulkaisujen tuotantomääriä.

Juhlapuheissa uuden yliopistolain katsottiin turvaavan tai jopa lisäävän tieteenteon ja yliopistotoimintojen autonomiaa (Lappalainen 2012, 28-34; Tomperi 2009, 190-195). Tämä pitääkin paikkaansa, jos ajatellaan yliopistoinstituution suhdetta aiempaan "isäntäänsä", eli valtioon ja opetusministeriöön. Rahoitusmallien muutokset, monien hallintotehtävien siirtäminen ministeriöltä yliopiston johdon alaisuuteen ja suurempi päätäntävalta koulutuspolitiikassa toki laajentavat yliopiston autonomista päätäntävaltaa (Yliopistolaki 2009). Toisaalta samaan aikaan toteutettu yliopiston sisäisen hallintomallin muutos on saanut aikaan vallan keskittymisen ylimmälle johdolle ja hallitukselle (Patomäki 2009, 39-40). Mikäli yliopisto käsitetään instituutiona, autonomia siis lisääntyi. Jos yliopisto katsotaan kuitenkin yliopistolaisten yhteisöksi, autonomia on kaventunut (Reuter 2009, 208-210; Wallgren 2009, 213-225). Lisäksi on syytä muistaa, että toiminnan rahoituksen hankkiminen yksityiseltä sektorilta muodostaa aina samalla myös valtasuhteen rahoittajan ja rahoitettavan välille. Tämä ei ainakaan lisää autonomiaa, ei etenkään sellaisissa tilanteissa, joissa ulkopuolinen rahoitus on keskittynyt muutamalle suurelle tukijalle.

Yliopistopolitiikassa sekä Suomessa että ulkomailla on painotettu voimakkaasti tulosvastuuta ja asetettujen tavoitteiden saavuttamisen määrittelyä käyttämällä erityyppisiä mittareita (Adler \& Harzing 2009; Billaut ym. 2009; Hussain 2013, Mustajoki 2010; Palonen 2009, 48-55; Pakkasvirta 2009, 58; Patomäki 2009, 25-43). Näillä mittareilla mitataan tieteenteon laatua ja valmistuvien opiskelijoiden "tuotantovaatimuksia", rankataan tieteentekijöitä paremmuusjärjestykseen sekä arvioidaan yliopiston tasoa kansainvälisesti suhteessa muihin yliopistoihin. Erityisesti tämä poliittinen päätös ohjata monimutkaisten prosessien toimintaa käyttäen niiden analysointiin yksinkertaistavia mittareita, voidaan nähdä hyvin mielenkiintoiseksi osatekijäksi pohdittaessa kaikkia mahdolliseen spekulatiiviseen kuplaan johtavia suistumistekijöitä.

Vallitsevaa yliopisto- ja tiedepolitiikkaa voidaan pitää siis keskeisenä suistumistekijänä. Vaikka monet suistumistekijöistä ovatkin peräisin kansainvälisiltä kentiltä, niiden kansallinen soveltaminen on kuitenkin viime kädessä poliittinen päätös. Suomalainen poliittinen ohjaus on esimerkiksi luonut 
puitteet, missä englanninkielisten artikkeleiden määrällisesti suurilukuinen julkaiseminen kansainvälisissä tiedelehdissä katsotaan tieteenteon prioriteetiksi (Kallio 2013, 82-84; Valo 2013) ja kirjoilla olevien ulkomaalaisten opiskelijoiden tai tutkijoiden henkilömäärä osoitukseksi kansainvälistymistavoitteiden saavuttamisesta (Opetus- ja kulttuuriministeriö 2013a).

\subsubsection{Tekijänoikeuslainsäädäntö}

Nykymuotoinen tekijänoikeuslainsäädäntö lähtee otaksumasta, että digitaalista materiaalia koskevat omistus- ja käyttöoikeudet voidaan määritellä muutamaa erityispoikkeusta lukuun ottamatta samoin filosofisin periaattein kuin reaalimaailman esineiden ja asioiden omistus- ja hallintasuhteet (Tekijänoikeuslaki 1961; Vähämäki 2009, 120). Keskeisin ongelma tässä lähestymistavassa on se, että digitaalinen kopiointi on helppoa eikä vahingoita kopioitavaa alkuperäiskappaletta lainkaan. Nykylainsädäntö kieltää kuitenkin yksiselitteisesti kopioinnin ilman digitaalisen materiaalin omistajan lupaa, minkä vuoksi digitaalisen materiaalin hallinnasta ja sen käyttöoikeuksien kaupasta on tullut monien yritysten pääliiketoimintaa.

Digitaalista materiaalia koskevan tekijänoikeuslainsäädännön pääpiirteet ovat varsin yhteneväisiä kansallisten lakien erityispiirteistä huolimatta. Tieteellisten julkaisujen kohdalla tällä lainsäädännöllä on suuri merkitys, sillä se tekee yksiselitteisesti laittomaksi tiedelehdissä julkaistujen artikkelien levityksen suoraan tieteentekijältä toiselle, mikäli tekijänoikeudet itselleen vaatinut kustantaja näin haluaa. Koska tieteenteko perustuu aina aiemmin tutkittuun tietoon, on aiemmin tehtyjen tutkimusjulkaisujen ja -raporttien kysyntä tutkijoiden keskuudessa taattua niin kauan kun tiedettä tehdään. Osaltaan nykymuotoinen tekijänoikeuslaki siis mahdollistaa jatkuvan kysynnän ja tätä myötä monien tiedelehtien artikkeleiden myyntihintojen jatkuvan nousun.

\subsubsection{Tiedejulkaisut ja kustantajien toiminta}

Edellisessä luvussa yhdeksi suistumistekijäksi mainittu tekijänoikeuslainsäädäntö mahdollistaa tiedelehtien kustantajille nykymuotoisen liiketoiminnan. Tuotantomääriin perustuvan tulosjohtamisen tullessa yliopistopolitiikan pääideologiaksi (Palonen 2009, 48; Tomperi 2009, 145-202) 
on tutkijoiden tuotettava julkaistavaksi kelpaavaa materiaalia osoittaakseen täyttäneen tehtävänsä (Kallio 2013, 63-82). Tarjontaa julkaistavista tutkimustuloksista erityisesti suurten kustannusyhtiöiden omistamiin tiedelehtiin on siis paljon ja tekijänoikeuslainsäädännön turvin kustantajat voivat vaatia julkaistavan materiaalin tekijänoikeuksia itselleen. Tämän jälkeen nämä yhtiöt voivat kaupata julkaisua vapaasti joko paperilehtenä tai yhä useammin vain digitaalisessa muodossa (Beverungen ym. 2012), kysynnän ollessa taattua tieteen ehdottoman viittauksin osoitetun faktaperusteisuuden takia.

Aiemmin tiedelehdet olivat pitkälti tieteellisten seurojen omia julkaisuja. Niiden kohderyhmä oli tyypillisesti varsin suppea ja koostui usein oman seuran jäsenten lisäksi lähinnä kyseisen tiedelehden teeman piirissä työskentelevistä muista tutkijoista. Kustannusyhtiöiden palveluiden merkitys kasvoi erityisesti paperilehtien levikin laajentamiseksi. Ne toimivat eräänlaisina lehden omistaneen tieteellisen seuran ulkoistamina jakelukanavina. Sittemmin kustannusyhtiöt ovat perustaneet omia tiedelehtiä, mikä nykyään onkin jo trendinä monilla aloilla.

Näistä kustantajien omista tiedelehdistä on tullut niille tuottoisaa liiketoimintaa, jonka avulla ne voivat käytännössä lypsää rahaa yliopistosektorilta mitättömällä riskillä (Beverungen ym. 2012; Palonen 2009, 48). Julkaisuihin tähtäävä tutkimustyö tehdään pääasiassa yliopistoissa ja julkaisujen laatua valvova vertaisarviointi toteutetaan usein työläydestään huolimatta tieteellisten periaatteiden mukaisesti ilman konsulttipalkkioita (MacDonald \& Kam 2007). Tutkimuspaperin ollessa hyväksytty julkaistavaksi tutkija tai tutkimusryhmä luovuttaa tekijänoikeudet yleensä korvauksetta kustannusyhtiön omistamalle lehdelle, joka tämän jälkeen myy eteenpäin kyseistä artikkelia usein hyvin korkeaan hintaan (Beverungen ym. 2012; Willmott 2011). Provisioita työn tehneille tutkijoille tai yliopistolle ei yleensä makseta. Mielenkiintoisena piirteenä voitaneen pitää sitäkin, että tutkijan halutessa paperinsa avoimeen levitykseen, hän joutuu usein itse maksamaan siitä lehdelle varsin merkittävän palkkion (Beverungen ym. 2012; Bohannon 2013). Tämän mahdollistaa aiemmin mainittujen poliittisten päätösten lisäksi osaltaan myös tutkijakunnan hajanaisuus (Palonen 2009, 45-55): Tutkijoiden ammattiliitot ovat heikkoja ja usein kansallisia, väliaikaisesti tutkijoina toimivia jatko-opiskelijoita on artikkeleiden kirjoittajien 
joukossa paljon, eikä yliopistojen tieteellisillä kirjastoilla ole juurikaan yhteistoimintaa julkaisujen hankinnassa - etenkään ylikansallisesti.

Tilanteessa ei näyttäisi olevan lainkaan kyse vapaiden markkinoiden logiikasta. Teollisuusyrityskään ei luovuta tuotteitaan ilmaiseksi jälleenmyyjille myytäväksi kuluttajille kalliiseen hintaan. Esimerkin yritys ei etenkään ole valmis maksamaan jälleenmyyjille tuotteidensa jakeluun ottamisesta, mikäli yritys jostain syystä haluaisi kuluttajien saavan tuotteet käyttöön vastikkeetta. Tieteellisessä julkaisemisessa kustannusyhtiöt kuitenkin useissa tapauksissa olettavat tutkijoiden luovuttavan työnsä tekijänoikeudet yhtiölle ilmaiseksi (jotta yhtiö voi jälleenmyydä artikkelia). Mikäli tutkija haluaa artikkelinsa vapaaseen levitykseen kustannusyhtiön omistamassa lehdessä, on hänen maksettava lehdelle oman artikkelinsa julkaisukorvaus. Tiedelehtien muuntuessa enenevissä määrin vain digitaaliseen muotoon asia muuttuu entistä järjettömämmäksi, kun paperilehden painatus- ja jakelukustannukset jäävät realisoitumatta (Beverungen ym. 2012).

Erinomaista tulosta tuottavasta liiketoiminnasta huolimatta julkaisutoiminta on kuitenkin pysynyt vahvasti muutaman suuren kustannusyhtiön dominoimana (Beverungen ym. 2012). Todellista kilpailua julkaisumarkkinoilla on näiden kesken ollut varsin vähän. Osittain syynä ovat todennäköisesti helpon rahan perässä julkaisumarkkinoille tulleet niin kutsutut saalistavat tiedelehdet (Bohannon 2013), joiden laatu on kirjava ja tieteellisten periaatteiden kunnioittaminen vähäistä. Lisäksi suurten kustannusyhtiöiden omilla laatulistoilla ja muilla rankingpalveluilla on todennäköisesti osuutensa heidän toimittamiensa lehtien menestykseen (Adler \& Harzing 2009; Butler \& Spoelstra 2012; Cederström \& Hoedemaekers 2012).

\subsubsection{Internet ja muut mediat}

Internet on nykyisistä tietoliikennevälineistä monessa mielessä ylivoimaisesti tehokkain. Internet toimii lähes reaaliaikaisesti ja mahdollistaa interaktiivisen tiedonvaihdon usean osapuolen välillä. Se on myös hyvin monipuolinen verrattuna perinteisiin medioihin, kuten radioon, televisioon tai sanomalehteen. Internetissä toimiminen ei myöskään vaadi käyttäjältä suuria sijoituksia tekniikkaan tai monimutkaista lupaprosessia. Lisäksi 
internetin avulla saa nopeasti yhteyden lähes minne päin maailmaa tahansa.

Internet on tarjonnut erityisesti yliopisto- ja tiedemaailmalle tehokkaan välineen ajatuksien, materiaalin, kannanottojen ja julkaisuiden jakamiseksi. Se on myös mahdollistanut kustannusyhtiöiden omien tiedelehtien jakelumarkkinoiden nopean laajenemisen sekä lukuoikeuksien tilaamisen sähköisesti luottokorttimaksulla mistä päin maailmaa tahansa. Internet on myös helpottanut merkittävästi yliopistojen, tiedelehtien tai muiden instanssien keskinäistä vertailua tarjoamalla kanavan, jonka kautta on mahdollista hakea mainituista instansseista huomattavia määriä dataa näiden rankkauksien perusteeksi (Adler \& Harzing 2009; Mustajoki 2010; Willmott 2011). Ilman internetiä esimerkiksi Shanghain listan (shanghairanking.com; Billaut ym. 2009) teko tai siteerausindeksien määrittäminen olisi huomattavasti työläämpää.

Internetin vaikutusta yliopisto- ja tiedemaailmaan mahdollisesti kehittymässä olevaan spekulatiiviseen kuplaan ei voi vähätellä. Shiller huomauttaa, että tiedonvälityksen tehostamisella on yllättävän paljon vaikutusta ihmisten laumakäyttäytymiseen, mikä puolestaan voi johtaa kuplalle ominaiseen kehityskulkuun (Shiller 2000, 71-95). Esimerkiksi Alankomaiden tulppaanimania, jota pidetään ensimmäisenä suurena spekulatiivisena kuplana, ilmeni ensimmäisten sanomalehtien ilmestyttyä ja vastaavasti uutismedioilla näyttäisi olevan suuri rooli vuosien 1929 tai 1987 pörssiromahduksissa. Tulevaisuudessa saatamme oppia, mikä vaikutus internetillä on ollut 2010luvun vaihteen finanssi- ja velkakriisiin.

\subsubsection{Mittauskulttuuri}

Tulosjohtaminen edellyttää mittareiden laajamittaista käyttöä, jotta tulosjohtaja voi varmistua asettamiensa tavoitteiden saavuttamisesta. Tulosjohtamisesta on saatu hyviä kokemuksia massatuotannosta, missä tavoitteena on tuottaa mahdollisimman kustannustehokkaasti haluttu määrä tuotteita vaaditulla laatuasteella. Massatuotannossa tuotteiden määrä ja valmistamiseen vaaditut kustannukset ovat helposti mitattavissa ja laatu voidaan määritellä muun muassa reklamaatioiden avulla (esimerkiksi 90 \% tuotteista tulee kestää ensimmäisen käyttövuoden ilman takuuvikoja).

Suureiden mittaus onnistuu yksikäsitteisesti, mutta monimutkaisempien asiakokonaisuuksien mittaaminen on tällä lähestymistavalla käytännössä 
mahdotonta. Tämän seikan ei ole kuitenkaan annettu häiritä, kun mittareita on otettu laajamittaisesti käyttöön niin kansainvälisesti kuin yliopistojen sisäisestikin (Adler \& Harzing 2009; Mustajoki 2010; Rhoades ym. 2008). Vaikka mittareiden ongelmat ovatkin usein suhteellisen selviä ja niiden epäkohdista on julkaistu tutkimuksia (Billaut ym. 2009; Bohannon 2013; Willmott 2011), on poliittinen ohjaus kuitenkin mittauskulttuurille erittäin suosiollinen (Koski 2009, 106-112; Lappalainen 2012; Palonen 2009, 48; Tieteellisten seurain valtuuskunta 2014).

Mikäli mittarit ovat epätarkoituksenmukaisia, niiden kattava soveltaminen aiheuttaa monenlaisia ongelmia (Kallio 2013, 249-268). Yksi hankala ongelma on systeemin vaiheittainen muokkautuminen mittareiden luomaan tärkeysjärjestykseen perustuvaksi. Esimerkiksi yliopistojen uusi palkkausjärjestelmä (Patomäki 2009, 34-36) sekä poliittisen että operatiivisen johdon asettamat tavoitteet ovat osa tätä prosessia, ja hiljalleen myös niin sanotut "talon tavat" muokkautuvat mitattavien asioiden asettamaan tärkeysjärjestykseen (Ahonen 2012, 74-93; Kaakkuriniemi 2012, 104-119; Kiuru 2012, 54-57). Koska valta on systeemeissä kuitenkin aina rakenteissa, ei systeemiä enää palauteta helposti tarkastelujakson lähtöpisteeseen, vaikka mittauskulttuurista noin vain yllättäen luovuttaisiinkin.

Mittauskulttuurin tulokset ovat jo nähtävissä niin Suomessa kuin maailmallakin. Yliopistoja kehitetään tarkoituksenmukaisesti muun muassa organisaatiouudistuksin pärjäämään paremmin ranking-listoilla (Hakala ym. 2012; Hautamäki \& Ståhle 2012; Patomäki 2005; Tomperi 2009). Julkaisutuotannon painottaminen on johtanut tutkimustulosten pilkkomiseen ja määrätyillä listoilla pärjänneiden tiedelehtien suosimiseen (MacDonald \& Kam 2007). Managerialistisesti toteutetut johtamistapojen muutokset ovat johtaneet tutkijoiden ammatti-identiteetin heikkenemiseen (Knights \& Clarke 2012).

\subsubsection{Globalisaatio}

Yliopistomaailma on koko historiansa ajan ollut kansainvälinen. Tieteentekijät ovat aiemmin vaihtaneet ajatuksiaan pääasiassa kirjeitse ja opiskelijakunta on eurooppalaisissa yliopistoissa ollut usein jo keskiajalla peräisin useilta eri kulttuurialueilta, jolloin yhteisenä kielenä oli usein latina. Yliopistojen muuttuessa enemmän koko kansan yliopistoiksi korkeakoulutuksen 
suosion ja mahdollisuuksien laajetessa ennennäkemättömästi 1900-luvun aikana yliopistot olivat ehkä kansallisempia kuin koskaan. Tämän ajanjakson kehitystä tukivat osittain myös tuona aikana vaikuttaneet vahvat kansallisvaltiot, tosin tiedettä tehtiin tuohonkin aikaan yli kansallisten rajojen (Volanen 2009, 130-132).

Sittemmin yliopistoista on kuitenkin haluttu tehdä "uudestaan" kansainvälisiä (Lappalainen 2012; Ahonen 2012, 74-93). Tämä on ollut muun muassa Suomessa nimenomaan yliopistopoliittinen päätös, jossa kansainvälistyminen onkin kieltämättä viety aivan uudelle tasolle. Tieteenteossa se on tarkoittanut muun muassa kotimaisen julkaisemisen väheksyntää ja korkeakoulutuksessa ulkomaisten opiskelijoiden osuuden hyvin voimakasta kasvua (Opetus- ja kulttuuriministeriö 2013b, 11). On myös alettu pohtimaan ja myös käytännössä kokeilemaan koulutusvientiä (Opetus- ja kulttuuriministeriö 2013b; Tomperi 2009, 145-202; Yliopistolaki 2009), jolla tutkinto-ohjelmia tarjotaan lukukausimaksuja vastaan toistaiseksi EU:n ulkopuolelta tuleville opiskelijoille.

Tämä kansainvälistyminen on kuitenkin käytännössä ollut hyvin vahvasti amerikkalaistumista (Palonen 2009, 46). Se on tarkoittanut englannin kielen tunkeutumista opetustoimintaan laaja-alaisesti, tieteellisten artikkelien julkaisemista englanninkielisissä julkaisuissa ja amerikkalaisen yliopistolaitoksen usein kritiikitöntä ihannointia ja angloamerikkalaisten käytänteiden kopiointia uudistusten yhteydessä. Välillä englanninkielisen julkaisemisen tärkeys on mennyt jopa tutkimusjulkaisun oletetun kohderyhmän kielellisen osaamisen ohitse (Kallio 2013, 142).

\subsubsection{Meritokratia}

Nyky-yhteiskunta on monessa mielessä suhteellisen meritokraattinen, eikä yliopistolaitos ole poikkeus. Tutkintoja arvostetaan usein jo pelkän tutkintonimikkeen perusteella ja moniin tehtäviin vaaditaan määrätyntyyppistä tutkintoa, minkä oletetaan samalla olevan osoitus osaamisesta. Usein muodollista pätevyyttä edellytetään myös tilanteissa, missä työn luonne vaatisi itse asiassa enemmänkin alan työkokemusta kuin sopivaa pohjakoulutusta. Yhteiskunnan instituutioissa tämä piirre korostuu lainsäädännön ja asetuksien vaatiessa usein viranhaltijoilta määrättyä koulutustasoa. Meriittien arvostamisesta kertoo myös usein käytännössä kohdattu tosiseikka, että 
pohjakoulutusvaatimuksista huolimatta varsinaiseen tutkintotodistukseen arvosanoineen kiinnitetään yllättävän vähän huomiota. Tämä on ymmärrettävää, mikäli tutkinnon suorittamisesta on kulunut aikaa ja varsinainen työkokemus on tuolloin merkittävämmässä asemassa osaamistasoa määriteltäessä. Kun näin toimitaan kuitenkin jo vastikään valmistuneiden kohdalla, kertoo se osaltaan tutkintonimikkeen meriitin arvostuksesta.

Viime vuosikymmeninä talouskasvu on ollut nopeaa monissa aiemmin varsin kehittymättömissä maissa, kuten esimerkiksi Kiinassa. Tämän seurauksena elintasoero monien kiinalaisten nykynuorten ja heidän vanhempiensa elämän nuoruuden välillä on suuri. Uudet jatkuvasti laajenevat kotimarkkinat tarvitsevat koulutettua työvoimaa ja koulutusta pidetään myös väylänä nousta yhteiskuntahierarkioissa ylemmäs ja parantaa elintasoa. Yliopistokoulutuksen voimakas arvostaminen näkyy myös länsimaisissa yliopistoissa kolmansista maista peräisin olevien opiskelijoiden ja opiskelemaan pyrkivien kasvavina määrinä.

\subsection{Vahvistusmekanismit}

Spekulatiivisen kuplan suistumistekijät eivät itsessään aiheuta kuplan syntymistä, vaan ne ovat toimintaympäristön reunaehtoja (Shiller 2000, 44-70). Itseään vahvistavan spekulatiivisen kuplan kehittymiseksi tarvitaan systeemin sisäisiä vahvistusmekanismeja, jotka perustuvat usein suistumistekijöihin tai niiden osa-alueisiin ja jotka vahvistavat niiden keskinäistä vuorovaikutusta. Näitä vahvistusmekanismeja kuplista löytyy lähes aina useampia ja usein ne ovat myös osittain päällekkäisiä. Yliopisto- ja tiedemaailmassa havaitaan ainakin kuvassa 1 esitetyt takaisinkytkennät systeemin eri osa-alueiden väliltä. 


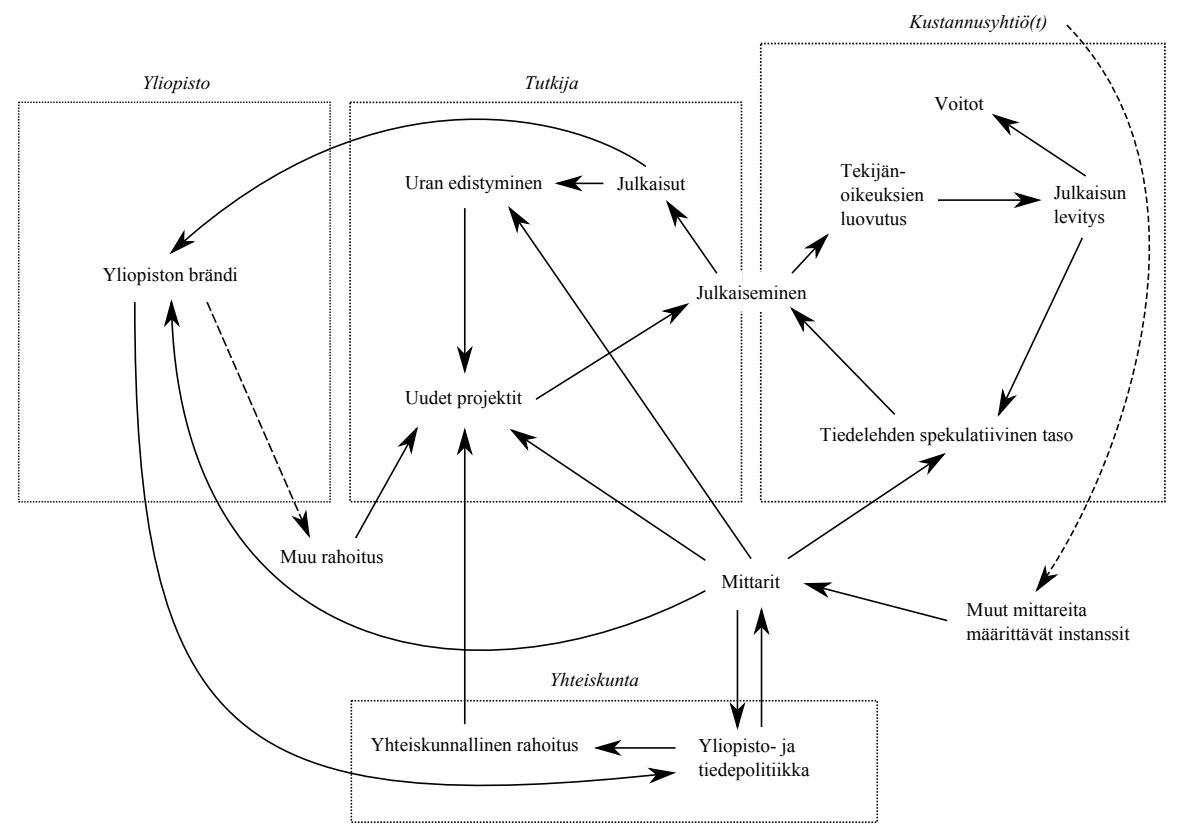

KUVA I: JULKAISUPROSESSIN YMPÄRILLE MUODOSTUVA VAHVISTUSMEKANISMI

Kuvassa 1 esitetyssä kaaviossa näkyy useita tutkimustulosten julkaisuprosessin ympärille kehittyneitä vahvistusmekanismeja. Koko systeemissä voidaan nähdä neljä laajempaa osakokonaisuutta, joita ovat yliopisto instituutiona, tutkija itse tieteentekijänä, yliopisto- ja tiedepolitiikka sekä kustannusyhtiöiden hallitsema tutkimusjulkaisuiden levitysprosessi. Näiden osa-alueiden ulkopuolelle on jätetty yksityiseltä sektorilta tuleva tutkimus- ja yliopistorahoitus sekä mittarit, jotka sisältävät useiden eri instanssien määrittelemiä menetelmiä asettaa yliopistot, tutkimusryhmät, tutkijat ja muut mitattavat tekijät paremmuusjärjestykseen.

Kuvassa 1 esitetyssä systeemissä on nähtävissä neljä itseään vahvistavaa takaisinkytkentäsilmukkaa. Ensimmäinen silmukka syntyy tutkijan työskentelytoiminnasta. Tutkija saa julkaisuprosessin (ks. julkaiseminen) seurauksena nimiinsä julkaisuja (ks. julkaisut) artikkeleiden tullessa hyväksytyksi tiedelehtiin. Nämä edistävät hänen uraansa (ks. uran edistyminen) hyvin monella tavalla (Butler \& Spoelstra 2012; Cederström \& Hoedemaekers 
2012; Kallio 2013, 121-194). Tämä tuo hänelle yleensä uusia työmahdollisuuksia erityisesti hänen työskennellessään määräaikaisena työntekijänä, sekä tutkimusrahoitusta (ks. uudet projektit). Toiminnan rahoituksen jatkuessa hän voi tehdä lisää tutkimustyötä ja kirjoittaa tuloksista lisää artikkeleita lähetettäväksi julkaisuprosessiin. Uran edistyminen määritellään monenlaisin mittarein (ks. mittarit). Lisäksi uusien projektien tutkimusongelmia valittaessa on käytetyillä mittareilla usein myös keskeinen asema (Hakala ym. 2003; Palonen 2009, 48; Patomäki 2005, 83-115). Sellaisia kysymyksiä tutkitaan mieluiten, mistä voidaan saada suhteellisen nopeasti julkaisukelpoisia, mitattaviksi sopivia tuloksia.

Julkaisuprosessista yliopiston kautta kiertävä takaisinkytkentäsilmukka lähtee varsin yleisestä oletuksesta, että yliopiston tutkijan nimiinsä saamat julkaisut (ks. julkaisut) ovat "kunniaksi" myös yliopistolle (Ahonen 2012, 74-103; Cederström \& Hoedemaekers 2012, 229-233). Tämän seurauksena yliopiston tutkijoiden tuottamia julkaisuja nykyään mitataankin monenmoisin mittarein, joista yksinkertaisemmat perustuvat lähinnä julkaisumäärien laskentaan. Monimutkaisemmat mittarit pyrkivät huomioimaan myös julkaisun laadun soveltaen yleensä jotain toista mittausmenetelmää artikkelille valitun julkaisufoorumin evaluointiin (Parker \& Weik 2014; Prasad 2013). Yliopiston tasoa (ks. yliopiston brändi) arvioitaessa näillä mittareilla on nykyään keskeinen asema (Billaut ym. 2009, 237-263; Willmott 2011, 429-442), minkä katsotaan mahdollistavan tutkimustyön (ks. uudet projektit) jatkumisen ja yleensäkin uusien projektien aloittamisen julkaisujen tuottamiseksi (ks. julkaiseminen). Tällä mahdollistamisella tarkoitetaan usein yliopiston oletettua vetovoiman kasvua (Billaut ym. 2009; Mustajoki 2010). Sillä toivotaan olevan vaikutusta uusien, usein kansainvälisten kykyjen saamiseksi opiskelijoiksi, opettajiksi, professoreiksi tai tutkijoiksi. Lisäksi sillä voidaan olettaa olevan positiivista vaikutusta ulkopuolisen rahoituksen (ks. muu rahoitus) hankkimiseksi tutkimusprojekteille.

Yliopistot ovat Suomessa nykyään muodollisesti autonomisia, mutta tosiasiallisesti julkisrahoitteisia, tulosvastuullisia laitoksia (Lappalainen 2012, 28-34; Tomperi 2009, 145-202; Yliopistolaki 2009). Tämä hallintomalli saa aikaan kuvassa 1 esitettyyn yliopiston kautta kulkevaan silmukkaan toisen haaran, missä yliopiston saavuttamat tulokset (ks. yliopiston brändi) vaikuttavat vallitsevan yliopistopolitiikan (ks. yliopisto- ja tiedepolitiikka) kautta suoraan yliopiston yhteiskunnalta saamaan rahoitukseen 
ja sitä kautta yliopiston toimintamahdollisuuksiin (ks. uudet projektit) (Opetusministeriö 2013a).

Julkaisutoiminnassa syntyvä takaisinkytkentäsilmukka alkaa artikkelin hyväksyntään päättyvästä vertaisarviointiprosessista (ks. julkaiseminen). Tämän jälkeen artikkelin kirjoittajat luovuttavat tekijänoikeudet kustannusyhtiölle (ks. tekijänoikeuksien luovutus) monissa tapauksissa vastikkeetta (Beverungen ym. 2012, 929-938). Joissain tapauksissa tekijä voi joutua jopa maksamaan siitä, että hän luopuu tekijänoikeuksistaan (Bohannon 2013). Tämän jälkeen kustannusyhtiö huolehtii artikkelin levityksestä (ks. julkaisun levitys) joko perinteisenä paperilehtenä tai digitaalisessa muodossa, ja kerää myydyistä vedoksista voitot (ks. voitot) itselleen. Julkaistut artikkelit vaikuttavat valittujen mittareiden määrittämällä tavalla tiedelehden oletettuun tasoon (ks. tiedelehden spekulatiivinen taso) (Adler \& Harzing 2009; Beverungen ym. 2012), joka vastaavasti tekee lehdestä tutkijalle houkuttelevamman julkaisufoorumin. Houkuttelevuus kasvaa, sillä tutkijan uran edistymisen yksi määritelmä on mittareiden perusteella "laadukkaammissa" tiedelehdissä julkaistut artikkelit (Tieteellisten seurain valtuuskunta 2014; Willmott 2011).

Mielenkiintoisen silmukan muodostaa myös kustantamojen vaikutus mittareita määritteleviin instansseihin (ks. muut mittareita määrittävät instanssit). Tämä vaikutus voi tapahtua esimerkiksi siten, että kustantamo ylläpitää omia mittareitaan (kuten Thomson Scientific tai Elsevier), rahoittaa tai tukee muuten näitä instansseja, tai vaikkapa medioiden tai lobbauksen kautta levittää tietoa, mitä mittareita tulisi pitää "laadukkaina" (Cederström \& Hoedemaekers 2012, Prasad 2013). Oli tämä taustavaikutus sitten millaista tahansa, sillä on todennäköisesti merkittävästi vaikutusta siihen, minkä tyyppisiä mittareita (ks. mittarit) valitaan käytettäväksi ja kuinka tiedelehtiä rankataan (ks. tiedelehden spekulatiivinen taso).

Katsottaessa lopuksi kuvassa 1 esitettyjen prosessien muodostamaa kokonaisuutta, voidaan tutkimustyön rahoitusprosessissa nähdä myös merkittävä epätasapaino. Yritystoiminnan luonteeseen kuuluu, että toimintaa pyörittävä yritys vastaa toiminnasta aiheutuvista kuluista kantaen täten myös yritystoimintariskin ja myydessään tuotteitaan markkinoille pyrkii saamaan prosessista taloudellista hyötyä liikevoittoina. Tieteellisten artikkeleiden tie kaupallisten kustantajien lehtiin poikkeaa tästä kuitenkin keskeisiltä osilta. Tutkimustyön rahoitus tapahtuu joko julkisin tai yksityisin 
varoin, mutta molemmissa tapauksissa kustantajat eivät tähän rahoitukseen osallistu. Markkinatalousperiaatteen mukaan esimerkiksi arvioitujen artikkeleiden huutokauppa tiedelehtien kesken olisi huomattavasti loogisempi toimenpide, jolloin kustantamo joutuisi aivan eri tavoin kantamaan taloudellisen riskin ja vastaavasti osallistuisi tätä kautta myös tutkimustyön rahoittamiseen.

\subsection{Laaja-alainen spekulatiivinen yliarvostus}

Tavallisista suhdannevaihteluista spekulatiivisen kuplan erottaa vaihteluiden suuruusluokka ja niiden tapahtuminen usein lyhyellä ajanjaksolla. Tämän kaltaiseen kehitykseen suistuminen edellyttää vallitsevien suistumistekijöiden ja niistä muodostuvan vahvistusmekanismin lisäksi myös kuplan kehitykseen osallistuvilta ihmismassoilta määrätynlaista psykologista asennoitumista ja laumakäyttäytymistä (Shiller 2000, 135-170). Yksi näkökulma tähän kysymykseen saadaan tarkastelemalla motiiveja, jotka liittyvät ihmisten toimintaan spekulatiiviseen kuplaan suistuvassa talouden osa-alueessa. Otan seuraavaksi esille korkeakoulutuksen ja tieteellisen tutkimuksen motivaattoreita ja vertaan niitä asuntomarkkinoiden kuplien oletettuihin motivaattoreihin (kuva 2).

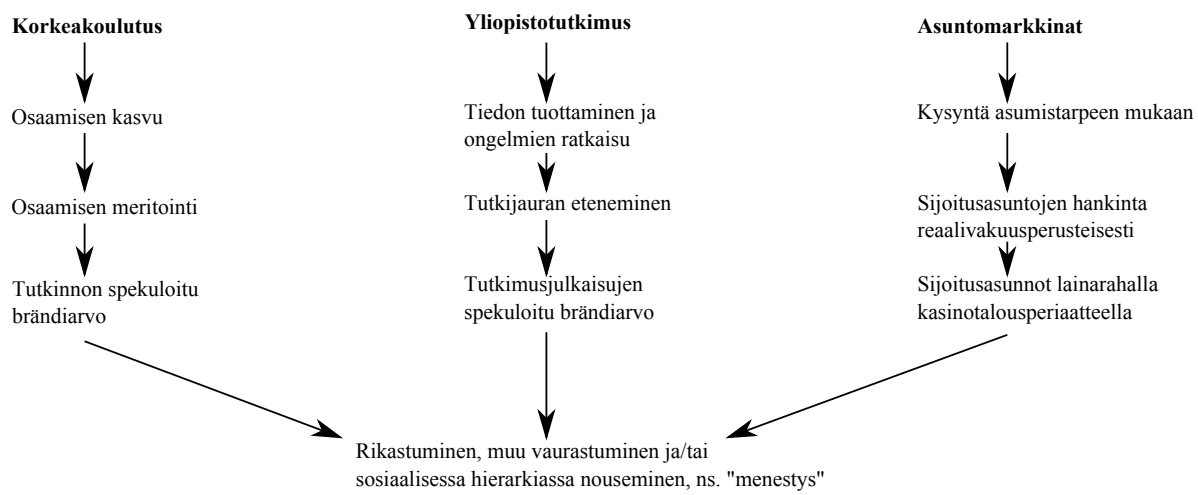

KUVA 2: MOTIVAATTORIT 
Kuvassa 2 esitetyt motivaattorit ovat järjestelty siten, että välittömästi teemaotsikon alla on primäärinen motivaattori, minkä pitäisi olla myös perustavanlaatuinen syy suurimmalle osalle systeemissä mukana olevista ihmisistä. Suurimman osan opiskelijoista tulisi siis olla yliopistolla kasvattaakseen omaa osaamistaan. Yliopistossa tehtävän tutkimuksen tavoitteena tulisi olla havaittujen ongelmien ratkaiseminen uutta tietoa tuottamalla. Vertailun vuoksi asuntomarkkinat toimivat terveellä pohjalla, mikäli ihmisten asumiseen liittyvät reaaliset tarpeet lähtökohtaisesti määräävät asuntojen kysynnän. Tällainen olisi ideaalitilanne, missä jokainen systeemiin osaa ottava ihminen tekisi päätöksiään oman tahtonsa mukaisesti primäärisiä motivaattoreitaan seuraten. Shillerin mukaan käytännössä tilanne menee kuitenkin usein hänen esittämänsä ravintolaesimerkin mukaisesti: jokainen asiakas valitsee kahdesta vaihtoehdosta ravintolan lounaspaikakseen sen mukaan, kumman ravintoloista uskoo paremmin täyttävän lounaalle asettamansa odotukset (Shiller 2000, 152). Seuraavat asiakkaat väistämättä huomaavat edellisten valinnat, joilla on vaikutusta heidän päätöksiin. Täydempi ravintola katsotaan todennäköisemmin laadukkaaksi ruokapaikaksi, jolloin entistä useampi asiakkaista haluaa lounastaa kyseisessä ravintolassa. Tämänlainen inhimillinen laumakäyttäytyminen on kuitenkin myös taustalla valittaessa asuntoja, haettaessa yliopistoon opiskelemaan tai pohdittaessa uusia tutkimuskysymyksiä.

Asuntomarkkinoilla tapahtuu aina asuntokauppaa myös sijoitusmielessä. Kun sijoitusasuntokauppa säilyy riittävän vähäisenä ja perustuu joko ostajien omalla rahalla tai reaalivakuuksilla saatuun rahoitukseen, ei ylikuumentumisongelmia yleensä ilmene. Markkinoiden ylikuumentuminen sitä vastoin voi uhata, mikäli sijoitusasuntokauppa kasvaa rajusti suhteessa asuntojen normaaliin käyttötarkoitukseen perustuvaan reaalikysyntään ja kauppojen rahoitus toteutetaan laajasti asuntojen spekulatiivisiin arvoihin tai kenties jopa futuuriarvoihin perustuviin lainoituksiin (Shiller 2000, 228-231). Tuolloin usein seuraavasta kovasta kysynnästä johtuva asuntojen nopea arvonnousu luo mahdollisuuksia muun muassa rikastumiseen asuntokaupalla ja toisaalta aiheuttaa myös pelkoa asunnon ostamisen mahdottomuudesta tulevaisuudessa hintojen ollessa liian korkeita. Tämä prosessi houkuttelee lisää asunnon ostajia markkinoille nostamaan kysynnän kasvaessa löysällä rahalla maksettuja asuntojen hintoja edelleen (Shiller 2000, 222-224), jolloin markkinat ovat suistuneet kuplaan johtavaan kehitykseen. 
Yliopistosektorilla vastaava tilanne syntyy, kun yliopistotyö selkeästi irtoaa edellä kuvatuista perustehtävistä. On luonnollista, että tutkimuksen tekeminen ja tutkimusongelmien ratkaisu johtaa myös tutkijanuran edistymiseen. Mikäli kuitenkin julkaisumäärät tai -paikat alkavat painamaan tutkimustyössä ongelmien ratkaisuja enemmän (Hussain 2013; Kallio 2013, 261-268; Koski 2009, 109-112; Palonen 2009, 47-49; Willmott 2011) ja näillä katsotaan olevan merkittävä rooli uran edistymisen suhteen, ollaan vaarassa suistua kuplaan. Siinä missä kasinotalouteen perustuvilla asuntomarkkinoilla yhä useampien viaton tavoite on vain rikastua, on vastaavasti tieteenteon tavoitteena sosiaalisessa hierarkiassa nouseminen uran edistyessä (Kallio 2013, 160-177). Vastaava kehityskulku voidaan nähdä myös yliopistokoulutuksen tavoitteissa. Tutkintonimikkeen tai tutkinnon myöntäneen yliopiston painoarvo ei saisi olla huomattavasti suurempi kuin tutkinnon edellyttämän osaamisen arvo.

Mikäli merkittävän suuri osa yliopistoista ottaa siis tavoitteekseen esimerkiksi valitun mittarin osoittaman nousun hierarkiassa, määrää tämä lähestymistapa käytännössä koko kuvassa 2 esitetyn ketjun tarkoitusperusteet. Tuolloin perustarkoituksena ei ole enää tutkimus ja opetus, vaan niistä tulee lähinnä välineitä, joilla tavoitellaan valittua uutta perustarkoitusta, eli hierarkiassa kohoamista. Välineen arvo taas perustuu sen kykyyn täyttää sille asetetut tavoitteet, minkä vuoksi tuolloin tutkimustyön perustarkoitus ei ole enää uuden tiedon tuottaminen tai ongelmien ratkaisu, vaan kyky tuottaa valittujen mittareiden osoittamalla hierarkiassa mahdollisimman korkealla olevilla foorumeilla julkaistaviksi kelpaavia artikkeleita. Vastaavasti opetuksen välineellinen tarkoitus ei mainitussa tilanteessa ole kasvattaa opiskelijoista tulevaisuuden osaajia, vaan tutkintojen tuottaminen tulostavoitteisesti ja mahdollisimman kustannustehokkaasti. Tässä tapauksessa opetus on usein tarkoituksenmukaisinta toteuttaa massakurssein ja toiminta rahoittaa joko lukukausimaksuin tai tulosperusteisesti jaetulla yhteiskunnallisella rahalla. Ero on suuri verrattuna tilanteeseen, missä opiskelijat ovat kasvamassa asiantuntijoiksi ja tutkimuksen tarkoituksena on tuottaa uutta tietoa. 


\subsection{Uuden aikakauden tietoyhteiskunta}

Shillerin mukaan yksi spekulatiivisille kuplille tyypillinen piirre on ajatus uudesta aikakaudesta, jossa vanhat säännöt eivät enää päde (Shiller 2000, 96-117). Viimeisten vuosikymmenien aikana onkin tapahtunut merkittäviä muutoksia, jotka voivat luoda illuusion uudesta aikakaudesta uusin säännöin. Maailmankauppa on globalisoitunut voimakkaasti viimeisten vuosikymmenien aikana, kun perinteinen teollisuus on siirtynyt kehittyviin maihin siinä missä monien perinteisten teollisuusmaiden taloudessa ovat painottuneet palvelu- ja tietotyö. Entinen kommunistinen itäblokki on hajonnut ja länsimaissa julkista sektoria on muokattu uusliberalististen ihanteiden mukaisesti (Patomäki 2005, 58-82; Patomäki 2009, 25-43). Koko tämän suuren taloudellisen murroksen tuloksena suuret määrät ihmisiä erityisesti Aasiassa ovat nousseet köyhyydestä ja esimerkiksi Kiinaan ovat muodostuneet voimakkaasti kasvavat sisämarkkinat. Maailmanlaajuisesti tarkasteltaessa tämä kehitys on luonut massiivista kysyntää myös korkeakoulutukselle (Opetus- ja kulttuuriministeriö 2013b), internetin mahdollistaessa tiedonvaihdon käytännössä reaaliajassa.

Monelta kantilta asioita katsottaessa maailma on siis todella muuttunutkin merkittävästi. Järkevä optimismi ja uusien mahdollisuuksien hyödyntäminen on tavoiteltava asia niin yksilölle kuin yhteiskunnallekin. Spekulatiivisen kuplan kasvualustaksi tämä ajattelu muuttuu, mikäli järkevä optimismi muuttuu järjettömäksi innostuneisuudeksi, missä realiteetit unohtuvat ja kaikkeen uudeksi nimettyyn suhtaudutaan kritiikittömästi "tulevaisuuden strategisina valintoina". Esimerkiksi IT-kuplan "hulluina vuosina" 2000-luvun vaihteessa saattoivat pienten ohjelmistotalojen pörssiarvot olla mielikuvituksellisen suuria. Vastaava ilmiö on nähtävissä myös monien asunto- tai finanssikuplien yhteydessä (Kiander 2001, 16-22; Shiller 2000, 118-123).

Yliopistoissa tähän uuden aikakauden alkuun liittyviä järjettömän innostuneisuuden tekijöitä nähdään ainakin voimakkaassa halussa tavoitella suuria julkaisumääriä laadukkaiksi uskotuissa tiedelehdissä (Hussain 2013; MacDonald \& Kam 2007; Willmott 2011). Myös suhtautuminen kansainvälisyyteen, käytännössä amerikkalaistumiseen tai ainakin englanninkielistymiseen, on hyvin positiivista (Opetus- ja kulttuuriministeriö 2013b). Palkkausjärjestelmä ja yliopiston poliittinen strategia ja sen toimeenpano 
painottavat vahvasti englanninkielistä julkaisemista aiheesta, teemasta tai lukijoiden kielitaidosta riippumatta. Kansainvälinen tai sellaiseksi tulkittava toiminta katsotaan myös yliopiston etua ajavaksi riippumatta toiminnan sisällöstä. Tätä kehitystä vahvistaa managerialismin periaattein kehitetty uusi komentorakenne (Patomäki 2005, 74-82; Patomäki 2009, 25-43; Tomperi 2009, 145-202), missä kollegiaalinen "tehottomuus" on karsittu pois suoraviivaisen käskytyksen tieltä, mahdollistaen näin systeemin nopeamman reagoinnin. Samalla se kuitenkin muuttuu epästabiilimmaksi, kun päätöksenteko on riippuvaista pienen piirin mielipiteistä. Kansainvälisyyttä ja julkaisutuotantoa mitataan kansainvälisin mittarein, joiden antamien tuloksien perusteella koko systeemiä johdetaan ja muokataan haluttuun suuntaan.

Shiller pitää todennäköisenä (Shiller 2000, 148-170), että spekulatiivisten kuplien synnyssä ja kehityksessä ihmisten laumakäyttäytymisen lisäksi myös yksilöiden liiallisella itsevarmuudella on suuri merkitys. Myös yllä kuvatussa prosessissa näillä molemmilla tekijöillä on todennäköisesti suurikin vaikutus. Tämän vaikutuksen tarkempi arviointi kuitenkin edellyttäisi laaja-alaista tutkimusta, jossa perehdyttäisiin ihmisten suhtautumiseen tieteeseen, yliopistotutkimukseen ja niiden rankkauksiin yksinkertaistetuin mittarein. Koska tiede- ja yliopistomaailma on globaali, tulisi myös tällainen tutkimus toteuttaa globaalisti.

\section{Päätelmät}

Spekulatiivisen kuplan syntyminen yliopisto- ja tiedemaailmaan on toistaiseksi hypoteesi, sillä tämän tyyppistä kuplaa ei ole aiemmin syntynyt, eikä tällaisen kuplan kehityksestä, saturaatiovaiheesta ja puhkeamisesta ole siksi kokemusta. On myös mahdollista, että yliopistosektorin erityispiirteistä johtuen mahdollisesti kehittynytkin kupla ei koskaan puhkea esimerkiksi finanssi- tai asuntokuplien tapaan nopeasti ja rajusti aiheuttaen samalla markkinoiden paniikkireaktion; vaan korkeakoulutukseen, tieteentekoon ja julkaisutoimintaan liittyvä mahdollinen yliarvostus hitaasti tasaantuu.

Nykymuotoisen institutionaalisen kehityksen jatkuminen johtanee kuitenkin mahdollisesti siihen, että yliopistojen luonne ja tarkoitus muokkautuu askel askeleelta massatuotantoideologian periaatteiden mukaiseksi 
tayloristiseksi liukuhihnalaitokseksi. Tällainen kehityskulku on kieltämättä merkittävä poikkeama siitä, millaiseksi tietoyhteiskunta on mielletty esimerkiksi Castellsin ja Himasen artikkelissa (Castells \& Himanen 2001). Tällaisessa liukuhihnalaitoksessa (hieman kärjistäen ilmaistuna) opiskelijat behavioristisesti "kehitetään" tabula rasasta standardoiduiksi osaajiksi, ja tieteenteon tarkoitus ja arvo määritellään tutkimusjulkaisujen kappalemäärillä, rankingien indeksoimissa julkaisukanavissa (Beverungen ym. 2012; Cederström \& Hoedemaekers 2012; Kallio 2014; Mustajoki 2010). Tutkimusjulkaisujen arvon voidaan siis tältä pohjalta olettaa inflatoituvan niiden kappalemäärän kasvaessa jatkuvasti, puhuttiin sitten varsinaisesta tieteellisestä sisällöstä tai nykymuotoisen, mittaroidun systeemin esittämästä julkaisujen numeerisesta arvosta.

Julkaisuiden arvon inflaatiota voimistaa paitsi tieteellisen sisällön oletettu heikentyminen ja kappalemäärän paisuminen, myös niiden jatkuvasti nousevat hinnat (Beverungen ym. 2012). Tämä on ollut ainakin toistaiseksi varsin vallitseva kehityskulku, vaikka onkin syytä todeta, että esimerkiksi open access -julkaiseminen erilaisine variaatioineen on tähän kehityskulkuun merkittävä poikkeus. Toisaalta on myös syytä huomioida, että open access -nimitys sinänsä kätkee taakseen varsin suuren määrän erilaisia käytänteitä. Open access voi tarkoittaa julkaisuprosessia, josta taloudellista hyötyä ei tavoittele mikään osapuoli. Toisaalta open access -periaatteella toimivat myös monet kustannusyhtiöiden omistamat lehdet, joissa artikkelit ovat kyllä vapaassa jaossa, mutta joissa tekijät joutuvat maksamaan usein varsin korkeat julkaisupalkkiot lehden omistavalle yhtiölle saadakseen artikkelinsa julkaistavaksi (Bohannon 2013).

Tutkimusjulkaisujen inflatoituminen ei kuitenkaan sinänsä vielä riitä kuplahypoteesin perusteeksi, vaan lähinnä luo vision tiedemaailman tulevaisuudesta, missä kokeneemmilla tieteenharjoittajilla olisi tyypillisesti tuhansia artikkeleita nimissään, määrän kasvaessa tietysti jatkuvasti. Tällainen kehitys edellyttäisi varsinaisen uuden tieteellisen tutkimustiedon jatkuvaa vähenemistä julkaisua kohti, julkaisumielessä "varmojen" aiheiden valintaa tutkimusprojekteiksi, sekä artikkeleiden tekijöiden määrittelyn varsin väljää tulkintaa. Koska mainittu ongelma on viime vuosina alkanut saada enenevissä määrin huomiota (Adler \& Harzing 2009; Beverungen ym. 2012; Billaut ym. 2009; Bohannon 2013; Butler \& Spoelstra 2012; Cederström \& Hoedemaekers 2012; Hussain 2013), on todennäköistä, että 
mahdollisen kuplan puhkeaminen tapahtuu nimenomaan julkaisuprosessin ja -liiketoiminnan saavuttaessa kasvunsa rajat.

Vaikka olen tässä esittänyt analogioita mittareilla arvotettujen tutkimusjulkaisujen ja arvopaperien välille, suoraa vertailua näiden välille ei kuitenkaan voi tehdä. Eroavuuksia löytyy useita, kuten esimerkiksi osakkeiden varsin vapaa vaihdettavuus. Tutkimusjulkaisu on aina sidottu tekijöihinsä, eikä tekijyyttä (toisin kuin tekijänoikeuksia) voida tietenkään enää myöhemmin muuttaa, ostaa, myydä tai vaihtaa. Tämän vuoksi luvussa 2 esitettyjen takaisinkytkentöjen voimakkuus on oletettavasti keskeisessä asemassa puhuttaessa tiede- ja yliopistosektorin mahdollisesta kuplakehityksestä. Mikäli takaisinkytkennät ovat heikkoja, kehitys johtaa todennäköisesti pikemmin tutkimusjulkaisujen inflatoitumiseen eikä varsinaista kuplakehitystä ilmene. Jos takaisinkytkennät ovat vahvoja, ne kiihdyttävät osaltaan koko systeemiä, jolloin korjausliike julkaisuprosessin nykykehityksen saturaatiopisteen jälkeen on ainakin todennäköisempi.

Saturaatiopisteen saavuttaminen edellyttää yleensä rahoitusongelmia. Yliopistojen ja tutkimustoiminnan rahoitus poikkeaa eri valtioissa merkittävästi. Esimerkiksi Yhdysvalloissa monet yliopistot toimivat liikeyritysten tapaan keräten opiskelijoilta lukukausimaksuja ja myyden tutkimuspalveluja yrityksille tai muille ostajille. Lisäksi yhdysvaltalaiset yliopistot saavat myös merkittävästi lahjoituksia sekä yksityisiltä henkilöiltä että yrityksiltä, mitä maan verolainsäädäntökin tukee. Euroopassa julkisrahoitteisuus on ollut vallitsevampi käytäntö ja Suomessa perinteisesti kaikki yliopistot olivat vuoden 2009 uuteen yliopistolakiin saakka julkisrahoitteisia (Yliopistolaki 2009). Uusi yliopistolaki mahdollistaa säätiöpohjaiset yliopistot myös Suomessa, joskin näidenkin rahoitus tulee edelleen pääosin valtiolta.

Asian moniulotteisuutta lisäävät huomattavat erot eri tieteenalojen toimintatapojen välillä, vaikka näitä eroavuuksia onkin pyritty viimeaikaisessa koulutus- ja yliopistopolitiikassa yhdenmukaistamaan. Teknisten, kaupallisten ja luonnontieteellisten alojen toimintatavat muistuttavat ehkä selkeimmin kuvaamiani havaintoja yliopisto- ja tiedemaailmasta, siinä missä esimerkiksi humanististen alojen toimintatavat eivät ole kehittyneet yhtä nopeasti tähän suuntaan. Koska kaikki kuitenkin kuuluvat institutionaalisessa mielessä samaan yliopistolaitokseen, on mahdollista että nämä eroavuudet rajoittavat kuplan kehittymistä. Toisaalta yliopistopoliittiset valinnat luovat vaikutelman, että massajulkaiseminen kansainvälisissä, 
rankatuissa tiedelehdissä haluttaisiin tuoda tehokkuuden ja tuloksellisuuden nimissä normaalikäytänteeksi myös niille aloille, missä sellainen toiminta on toistaiseksi ollut vähäistä.

Yliopisto- ja tutkimusmaailman systemaattinen kyky sietää mahdollisia häiriötekijöitä riippuu paljolti siitä, miten pitkälle itse systeemiä on kehitetty markkinatalouslogiikan mukaan. Kuten aiemmin todettiin, julkinen rahoitus tasapainottaa merkittävästi yliopistolaitoksen toimintaa, vaikka julkaisuprosessissa tapahtuisikin nopealla aikavälillä merkittäviä muutoksia. Tuolloin voitaisiin puhua ehkä enemmänkin tiedelehtien kustantamoja koskeneesta kuplasta, mistä todennäköisesti seuraisi taloudellisia vaikeuksia kustantajille julkaisukanavien muuttuessa tai siirtyessä muille instansseille, jotka voisivat toimia esimerkiksi open access-periaatteella. Tällainen saturaatio voisi olla seurausta esimerkiksi uudentyyppisten mittareiden kansainvälisesti laajamittaisesta käyttöönotosta, laajasta mittaroinnista luopumisesta, tutkijakunnan kansainvälisestä järjestäytymisestä tai yksinkertaisesti käytettävissä olevien rahojen ja resurssien kasvun rajojen saavuttamisesta.

Inhimilliset systeemit ovat kuitenkin aina dynaamisia ja muokkautuvat jatkuvasti vallitsevien olosuhteiden mukaan. Myös yliopisto- ja tutkimusmaailma muokkautuu jatkuvasti vastaamaan muuttuvaa maailmaa. Yksi tällainen muuntumisprosessi on ollut liiketoimintalogiikkaan perustuvien käytänteiden leviäminen muun muassa tieteelliseen julkaisemiseen, jolla on ollut vaikutusta myös tieteentekoon. Mitä pidemmälle tämä kehitys johtaa, sitä todennäköisempää on, että julkaisuprosessissa ilmenevät häiriöt aiheuttavat taloudellisia vaikeuksia myös itse yliopistoinstituutiolle.

Yliopistoja ja tutkimusmaailmaa voidaan ohjata liiketoimintalogiikalla myös hienovaraisemmin. Kehitys Suomessa onkin edennyt viime aikoina tähän suuntaan. Vaikka pääosa rahoituksesta tulisikin julkiselta sektorilta, sen jakamista määritellään enenevissä määrin luomalla yliopistoihin sisäiset virtuaalimarkkinat. Tämä johtaa siihen, että tutkimusryhmät, laitokset, tiedekunnat ja vaikka kokonaiset yliopistotkin joutuvat kilpailemaan keskenään rahapotin jaosta tulosperusteisesti. Tällainen kehitys muokkaa systeemiä ja erityisesti sen rahoitusta perustumaan valittua tulosta osoittaviin mittareihin. Käytännön rahoitus arkipäivän tutkimus- ja yliopistotyössä muokkautuu näin epävakaammaksi, vaikka yliopistosektorin kokonaisrahoitukseen ei puututtaisikaan. Tämän kaltainen kehitys toisaalta voi johtaa varsinaisen kuplan sijasta myös niin sanottuun pysähtyneisyyden 
tilaan. Tällöin yliopistoissa tehtävä tutkimus näivettyy kovasta systeemin sisäisestä kilpailusta seuraavan vaihtelevan rahoituksen, yhteistoimintakyvyttömyyden ja arvoltaan inflatoituvien tutkimusjulkaisujen seurauksena.

Tutkimustyö vaatii tutkijoiden keskinäistä luottamusta, puhutaan sitten tulosten julkaisemisesta tai yliopistoissa tehtävästä tutkimuksesta. Myös prosessin rahoittajatahojen, niin yhteiskunnan toimielinten kuin mahdollisten muidenkin mesenaattien on kyettävä luottamaan siihen, että kenties pitkäänkin jatkuva, joskus näennäisesti tulokseton työ tieteen parissa voi lopulta johtaa jopa läpimurtoihin. Systeemin edellyttämästä luottamuksesta nousee tietysti kysymys, miten paljon luottamus kestää esimerkiksi vaikkapa valittujen mittareiden esille tulevia puutteita. Luottamuksen säröillessä vakavalla tavalla samaan aikaan julkaisuprosessin rahoitusongelmien kanssa, aiemmin esitettyjen takaisinkytkentäsilmukoiden vahvuus todennäköisesti ratkaisee, missä määrin tällainen häiriö sitten etenisi ja vaikuttaisi koko systeemin toimintaan. On vaikeaa olettaa, että tuollaisessa tilanteessa löytyisi rahoitusta nykymääräiseen inflatoituvien tutkimusjulkaisujen massatuotantoon. Lisäksi asiaa monimutkaistaa yliopisto- ja tiedemaailman kansainvälisyys. Häiriö voisi lähteä leviämään periaatteessa mistä tahansa päin maailmaa ja toisaalta vaikuttaa eri tavoin eri maiden yliopistolaitoksissa.

Loppukaneettina todettakoon, että yliopisto- ja tiedemaailma on käsitteenä laaja ja sen toimintakenttä on globaali, joten sen tulevan kehityskulun suuntaan vaikuttavat todella monet tekijät. Esittämäni hypoteesin toteutuminen edellyttää ainakin yliopisto- ja tiedemaailman kehityksen jatkumisen askel askeleelta markkinavetoisemmaksi. Toistaiseksi näyttäisi siltä, että tähän suuntaan oltaisiin menossa, mutta toisaalta esimerkiksi open access-julkaiseminen, yliopistopolitiikka ja mittareiden tuleva käyttö voivat muuntaa merkittävästi kehityskulkua. Aika näyttää, jääkö hypoteesi yliopisto- ja tiedemaailman spekulatiivisesta kuplasta hypoteesiksi vai ei.

\section{Yhteenveto}

Tässä artikkelissa olen käsitellyt yliopisto- ja tiedemaailmassa mahdollisesti kehittymässä olevaa spekulatiivista kuplaa. Tämän kuplan voi katsoa olevan muodostumassa erityisesti tiedemaailman julkaisuprosessiin, jossa 
tiedelehtiä omistavat kustannusyhtiöt kykenevät rahastamaan tutkimustulosten julkaisutoiminnasta olemattomalla riskillä suuria voittoja. Muun muassa tekijänoikeuslainsäädäntö, laajalle levinnyt mittauskulttuuri ja vallitseva uusliberalistinen yliopistopolitiikka mahdollistavat nämä voitot.

Spekulatiivisen kuplan suistumistekijöitä ovat ainakin yliopistopolitiikka, tekijänoikeuslainsäädäntö, kustantajien toiminta ja tieteelliset julkaisukäytännöt, internet, vallitseva mittauskulttuuri, globalisaatio ja meritokratia. Käsittelin näitä suistumistekijöitä pääpiirteittäin, todeten samalla, että muitakin suistumistekijöitä todennäköisesti löytyy. Analysoin suistumistekijöistä ja muista yliopisto- ja tiedemaailman tekijöistä muodostuvia itseään vahvistavia takaisinkytkentäsilmukoita ja niiden rakennetta. Käsittelin myös spekulatiivisille kuplille tyypillistä spekulatiivisen arvon kasvavaa poikkeamaa reaaliarvosta.

Käsittelin myös muita spekulatiivisen kuplan tekijöitä, kuten uusmedioiden roolia erityisesti takaisinkytkentöjen mahdollistajana ja tehostajana, käsitystä uuden aikakauden alkamisesta sekä ihmisten taipumusta laumakäyttäytymiseen. Jälkimmäiset vaativat kuitenkin vielä paljon lisätutkimusta, jotta tarkempia päätelmiä voidaan tehdä riittävällä varmuudella. Päätelmissä pohdin myös mahdollisesti kehittymässä olevan spekulatiivisen kuplan puhkeamista ja sen mahdollisia seurauksia.

\section{Lähteet}

Adler, Nancy ja Harzing, Anne-Wil. 2009. When knowledge wins: transcending the sense and nonsense of academic rankings. Academy of Management Learning E Education, 8:1, 72-95.

Ahonen, Pertti. 2012. Yliopistojen visiot, arvot ja missiot tulevaisuuden rakennusaineksina. Teoksessa Matti Vesa Volanen (toim.), Toiseksi paras? Tieteentekijät ja uusi yliopisto. Helsinki: Tieteentekijöiden liitto.

Beverungen, Armin, Böhm, Steffen ja Land, Cristopher. 2012. The poverty of journal publishing. Organization, 19:6, 929-938.

Billaut, Jean-Charles, Bouyssou, Denis ja Vincke, Philippe. 2009. Should you believe in the Shanghai ranking? Scientometrics, 84:1, 237-263. 
Bohannon, John. 2013. Who's afraid of peer review? Science, 342:6154, 60-65.

Butler, Nick ja Spoelstra, Sverre. 2012. Your excellency. Organization, 19:6, 891-903.

Cameron, Rondo. 1997. A concise economic history of the world. New York: Oxford University Press.

Castells, Manuel ja Himanen, Pekka. 2001. Suomen tietoyhteiskuntamalli. Helsinki: WSOY.

Cederström, Carl ja Hoedemaekers, Casper. 2012. On dead dogs and unwritten jokes: life in the university today. Scandinavian Journal of Management, 28:3, 229-233.

Hakala, Johanna. 2003. Tutkimuksen kansainvälistyminen: tieteellisestä turismista tiukkoihin tiimeihin. Teoksessa Johanna Hakala ym., Yliopisto - tieteen kehdosta projektimyllyksi. Yliopistollisen tutkimuksen muutos 1990-luvulla. Helsinki: Gaudeamus.

Hakala, Johanna, Kaukonen, Erkki, Nieminen, Mika ja Ylijoki, Oili-Helena. 2003. Yliopisto - tieteen kehdosta projektimyllyksi. Yliopistollisen tutkimuksen muutos 1990-luvulla. Helsinki: Gaudeamus.

Hautamäki, Antti ja Ståhle, Pirjo. 2012. Ristiriitainen tiedepolitiikkamme - suuntana innovaatiot vai sivistys? Helsinki: Gaudeamus.

Hussain, Simon. 2013. Journal list fetishism and the "sign of 4" in the ABS guide: a question of trust? Organization, doi: 10.1177/1350508413506763.

Kaakkuriniemi, Tapani. 2012. Onko yliopistossa enää mitään järkeä? Teoksessa Matti Vesa Volanen (toim.), Toiseksi paras? Tieteentekijät ja uusi yliopisto. Helsinki: Tieteentekijöiden liitto.

Kallio, Kirsi-Mari. 2014. Ketä kiinnostaa tuottaa tutkintoja ja julkaisuja liukuhihnaperiaatteella...? - Suoritusmittauksen vaikutukset tulosohjattujen yliopistojen tutkimus- ja opetushenkilökunnan työhön. Turun kauppakorkeakoulu, sarja A-1:2014.

Kiander, Jaakko. 2001. Laman opetukset. Suomen 1990-luvun kriisin syyt ja seuraukset. Helsinki: Valtion taloudellinen tutkimuskeskus, 27:5. 
Kiuru, Jarmo. 2012. Yliopistoyhteisön itsehallinto. Teoksessa Matti Vesa Volanen (toim.), Toiseksi paras? Tieteentekijät ja uusi yliopisto. Helsinki: Tieteentekijöiden liitto.

Knights, David ja Clarke, Caroline. 2012. It's a bittersweet symphony, this life: fragile academic selves and insecure identities at work. Presented at the 10th International Conference on Organizational Discourse, 18-20 July, 2012.

Koski, Leena. 2009. Yliopiston sisäisen järjestyksen muutos. Teoksessa Tuukka Tomperi (toim.), Akateeminen kysymys? Yliopistolain kritiikki ja kiista uudesta yliopistosta. Tampere: Vastapaino.

Lappalainen, Tuomo. 2012. Kuinka yliopistouudistuksesta tuli kaikkien aikojen fiasko? Suomen Kuvalehti, 43/2012, 28-34.

MacDonald, Stuart ja Kam, Jacqueline. 2008. Aardvark et al.: quality journals and gamesmanship in management studies. Journal of Information Science, 33:6, 702-717.

Marinetto, Mike. 2012. What are we to do with our "nice students"? The learning experience within the scholastic apartheid system of the research-led university. Organization, 20:4, 615-626.

Mustajoki, Arto. 2008. Tieteen julkaisuähky. Tieteessä tapahtuu, 26:5, 32-33.

Mustajoki, Arto. 2010. Yliopistojen rankingit - paljon melua tyhjästä? Tieteessä tapahtuu, 28:8, 20-29.

Nielsen, Michael ja Myers, Joanne. 2011. Reinventing discovery: The new era of networked science. Princeton: Princeton University Press.

Nieminen, Mika. 2003. Muuttuva yliopistollinen tutkimus - tehokkaammin, soveltuvammin, organisoidummin? Teoksessa Johanna Hakala ym., Yliopisto tieteen kehdosta projektimyllyksi. Yliopistollisen tutkimuksen muutos 1990-luvulla. Helsinki, Gaudeamus.

Nieminen, Mika. 2003. Tiede informaatioyhteiskunnan ja innovaatiojärjestelmän palveluksessa. Teoksessa Johanna Hakala ym., Yliopisto - tieteen kehdosta projektimyllyksi. Yliopistollisen tutkimuksen muutos 1990-luvulla. Helsinki, Gaudeamus. 
Niiniluoto, Ilkka. 1997. Johdatus tieteenfilosofiaan: käsitteen- ja teorianmuodostus. Helsinki, Otava.

Opetus- ja kulttuuriministeriö. 2013. Yliopistojen rahoitus uudistuu vuoden 2013 alusta. http://www.minedu.fi/OPM/Tiedotteet/2012/04/yliopistojen_rahoitus. html?lang=fi [Luettu 13.2.2014].

Opetus- ja kulttuuriministeriö. 2013. Suomi kansainvälisille koulutusmarkkinoille. Opetus- ja kulttuuriministeriön työryhmämuistioita ja selvityksiä, 2013:9.

Palonen, Emilia. 2009. Yliopistouudistus periferiassa. Teoksessa Tuukka Tomperi (toim.), Akateeminen kysymys? Yliopistolain kritiikki ja kiista uudesta yliopistosta. Tampere: Vastapaino.

Pakkasvirta, Jussi. 2009. Kun Universitatis muuttui projektiksi. Teoksessa Tuukka Tomperi (toim.), Akateeminen kysymys? Yliopistolain kritiikki ja kiista uudesta yliopistosta. Tampere: Vastapaino.

Parker, Martin ja Weik, Elke. 2014. Free spirits? The academic on the aeroplane. Management Learning, 45:2, 167-181.

Patomäki, Heikki. 2005. Yliopisto Oyj. Tulosjohtamisen ongelmat - ja vaihtoehto. Helsinki: Gaudeamus.

Patomäki, Heikki. 2009. Yliopisto konkreettisena utopiana: Kokemuksia Turusta Nottinghamiin ja Helsingistä Melbourneen. Teoksessa Tuukka Tomperi (toim.), Akateeminen kysymys? Yliopistolain kritiikki ja kiista uudesta yliopistosta. Tampere: Vastapaino.

Prasad, Ajnesh. 2013. Playing the game and trying not to lose myself: a doctoral student's perspective on the institutional pressures for research output. Organization, doi: 10.1177/1350508413486274.

Rhoades, Gary, Kiyama, Judy, McCormick, Rudy ja Quiroz, Marisol. 2008. Local cosmopolitans and cosmopolitan locals: New models of professionals in the academy. The Review of Higher Education, 31:2, 209-235.

Shiller, Robert. 2000. Irrational Exuberance. New Jersey: Princeton University Press. 
Tieteellisten seurain valtuuskunta. 2013. Julkaisufoorumi. http://www.tsv.fi/ julkaisufoorumi/ [Luettu 13.2.2014].

Tomperi, Tuukka (toim.). 2009. Akateeminen kysymys? Yliopistolain kritiikki ja kiista uudesta yliopistosta. Helsinki: Vastapaino.

Tutkimuseettinen neuvottelukunta. 2012. Hyvä tieteellinen käytäntö ja sen loukkausepäilyjen käsittely Suomessa. www.tenk.fi/sites/tenk.fi/files/HTK_ ohje_2012.pdf [Luettu 13.2.2014]

Reuter, Martina. 2009. Haave strategisesta ohjauksesta. Teoksessa Tuukka Tomperi (toim.), Akateeminen kysymys? Yliopistolain kritiikki ja kiista uudesta yliopistosta. Tampere: Vastapaino.

Valo, Maarit. 2013. Tiedeyhteisö norsunluutornissaan. Acatiimi 3/13.

Volanen, Matti. 2009. Yliopisto 3.0. Teoksessa Tuukka Tomperi (toim.), Akateeminen kysymys? Yliopistolain kritiikki ja kiista uudesta yliopistosta. Tampere: Vastapaino.

Vähämäki, Jussi. 2009. Tietopaja. Teoksessa Tuukka Tomperi (toim.), Akateeminen kysymys? Yliopistolain kritiikki ja kiista uudesta yliopistosta. Tampere: Vastapaino.

Ylijoki, Oili-Helena. 2009. Yliopiston lumo. Teoksessa Tuukka Tomperi (toim.), Akateeminen kysymys? Yliopistolain kritiikki ja kiista uudesta yliopistosta. Tampere: Vastapaino.

Yliopistolaki 558/2009. http://www.finlex.fi/fi/laki/alkup/2009/20090558 [Luettu 13.2.2014]

Wallgren, Thomas. 2009. Yliopiston autonomian kaventaminen. Teoksessa Tuukka Tomperi (toim.), Akateeminen kysymys? Yliopistolain kritiikki ja kiista uudesta yliopistosta. Tampere: Vastapaino.

Willmott, Hugh. 2011. Journal list fetishism and the perversion of scholarship: reactivity and the ABS list. Organization, 18:4, 429-442. 